\title{
The morphology of coconut fiber surface under chemical treatment
}

Muhammad Arsyad ${ }^{1}$, I Nyoman Gede Wardana ${ }^{2}$, Pratikto $^{2}$, Yudy Surya Irawan ${ }^{2}$

\author{
${ }^{1}$ Department of Mechanical Engineering, State Polytechnic of Ujung Pandang \\ e-mail: muhammadarsyadhabe@yahoo.co.id \\ ${ }^{2}$ Department of Mechanical Engineering, Brawijaya University, Malang, Indonesia \\ e-mail: wardana@ub.ac.id; pratiktoprawoto@yahoo.com; yudysir@ub.ac.id
}

\begin{abstract}
The objective of this study was to determine the effect of chemical treatment on the coconut fiber surface morphology. This study is divided into three stages, preparation of materials, treatment and testing of coconut fiber. The first treatment is coconut fiber soaked in a solution of $\mathrm{NaOH}$ for 3 hours with concentration, respectively $5 \%, 10 \%, 15 \%$, and $20 \%$. The second treatment is coconut fiber soaked in $\mathrm{KMnO}_{4}$ solution with a concentration of $0.25 \%, 0.5 \%, 0.75 \%$, and $1 \%$ for 3 hours. The third treatment is coconut fiber is soaked in $\mathrm{H}_{2} \mathrm{O}_{2}$ solution with a concentration of $5 \%, 10 \%, 15 \%$, and $20 \%$ for 3 hours. At each treatment the fiber is dried in an oven at a temperature of $90^{\circ} \mathrm{C}$ for 5 hours. Coconut fibers that had been the first, second, and third treated, sorted out for chemical composition, single fiber tensile and SEM testing. Tensile strength of single coconut fiber was tested following ASTM 3379-02 by using a tensile testing LR10K Plus $10 \mathrm{kN}$ Universal Materials Testing Machine. The fiber surface morphology was examined using electron microscopy Vega3 Tescan Scanning Electron Microscope (SEM) at $5 \mathrm{kV}$ voltage, and X-ray diffraction, $30 \mathrm{kV}, 15 \mathrm{~mA}$, at scan speed $2.000 \mathrm{deg} . / \mathrm{min}$. The result shows that the highest tensile strength of the fiber obtained in the first treatment namely N4. In general the mechanical strength of the fiber decrease slightly however, the fiber surface morphology becomes rough. $\mathrm{NaOH}$ treatments cause crystallization on the surface of the fiber. Crystallinity index was decreased with increasing concentration of $\mathrm{NaOH}$. The second treatment caused the trench grooves on the surface of the fiber that can improve bonding between fiber and matrix.
\end{abstract}

Keywords: coconut fiber, treatment, chemical, morphology, crystallization

\section{INTRODUCTION}

The main content of coconut fiber is cellulose, hemi-cellulose, and lignin. The lignin content in coconut fibers is very high $[1,2,3]$. Cellulose and hemi-cellulose is a polysaccharide compound while lignin is a macromolecules polyphenolic compound [2]. The strength or ductility of composite can be obtained by taking into account the bond between the fiber surface with a matrix, the way to construct the fiber, and reinforcer component should have a higher elastic modulus than the matrix. The properties of the composite is strongly determined by compatibility between natural fibers with a matrix [4]

Natural fibers have a hydrophilic nature [5]. In addition, the surface of natural fibers also has dirt and other substances that may affect the bonding strength of the fibers with the matrix. Therefore, various studies have been done to improve the surface of natural fibers in order to have a good bonding strength between natural fibers with the matrix. Coconut fiber is very good to be used as a filler in the composite because it has several advantages such as: strong, lightweight, heat resistant, salt water resistant, cheap, and easily obtained $[6,7]$.

Many ways of treatment has been done to improve the compatibility of natural fibers. The treatment, both physically and chemically, aims to modify the fiber surface. Chemical treatment is one method for improving the properties of natural fibers such as surface geometry, dirt removal, fiber strength, and the interaction between the fiber and the matrix []. Chemical treatment often used in natural fiber is alkali treatment. Alkali treatment is expected to remove most of hemicelluloses, lignin, waxes, and oils soluble in alkali, so that the fiber surface became rough because of reduced fiber aggregation [9]. Study on alkali treatment of the coconut fiber has been done by many researches $[\underline{9}, \underline{10}, \underline{11}, \underline{12}]$. There was a decrease in the 
fatigue life for a large stress composite reinforced with coconut fiber treated with sodium hydroxide [13].

In general, treated natural fibers used as a composite reinforce treatment give tensile strength and modulus of elasticity greater than the untreated natural fiber composites. Therefore, modification of the fiber surface treatment is considered to increase the strength of natural fiber Composite [13, 14]. Surface treatment using stearic acid and potassium permanganate other than $\mathrm{NaOH}$ provide a better performance than the untreated fibers [14]. Hydrogen peroxide $\left(\mathrm{H}_{2} \mathrm{O}_{2}\right)$ was also used in coconut fiber treatment [, $\underline{15}$ ]. In addition to chemical treatment, coconut fiber is treated by washing and boiling to remove dirt on the surface of the fiber so as to produce a cavity $[\underline{2}, \underline{16}]$.

Structural characteristics and chemical composition made tensile strength and modulus of elasticity of coconut fiber relatively low compared to other natural fibers. However, coconut fiber has special advantages such as large strain, low density, and weather resistant so that it is good for functional material [17].

Generally in previous studies, fiber was treated only in one step $[\underline{8}, \underline{9}, \underline{10}, \underline{16}]$ or two steps [18]. However, in this study chemical treatment for coconut fiber was done in three steps, namely first step was $\mathrm{NaOH}$ treatment, the second step was $\mathrm{KMnO}_{4}$ treatment and the third step was $\mathrm{H}_{2} \mathrm{O}_{2}$ treatment, with varying concentrations. Moreover, after each step of treatmen, the fiber was immediately dried in an oven without washed with distilled water [13]. The objective of this research is to study the effect of chemical treatment on coconut fiber surface morphology.

\section{MATERIALS AND METHODS}

Coconut fiber in this experiment was obtained by separating the fiber from coconut husk and corks. Chemical solution for fiber surface treatment was prepared by dissolving sodium hydroxide $(\mathrm{NaOH})$ in distilled water with the composition of $5 \%, 10 \%, 15 \%$, and $20 \%$; hydrogen peroxide $\left(\mathrm{H}_{2} \mathrm{O}_{2}\right)$ with the same composition, and the potassium permanganate $\left(\mathrm{KMnO}_{4}\right)$ with $0.25 \%, 0.5 \%, 0.75 \%$, and $1 \%$ as tabulated in Table 1 .

Table 1: Notation of coconut fiber surface treatment

\begin{tabular}{l|c|l}
\hline NOTATION & & \multicolumn{2}{l}{ TREATMENT } \\
\hline Without treatment & $\mathrm{N}$ & Untreatment \\
\hline \multirow{4}{*}{ The First Treatment $(\mathrm{NaOH})$} & $\mathrm{N} 1$ & $\mathrm{NaOH} 5 \%$ \\
\cline { 2 - 3 } & $\mathrm{N} 2$ & $\mathrm{NaOH} 10 \%$ \\
\cline { 2 - 3 } & $\mathrm{N} 3$ & $\mathrm{NaOH} 15 \%$ \\
\cline { 2 - 3 } & $\mathrm{N} 4$ & $\mathrm{NaOH} 20 \%$ \\
\hline \multirow{4}{*}{ The Second Treatment $(\mathrm{KMnO} 4)$} & $\mathrm{K} 1$ & $\mathrm{~N} 1$ soaked in $\mathrm{KMnO}_{4} 0,25 \%$ \\
\cline { 2 - 3 } & $\mathrm{K} 2$ & $\mathrm{~N} 2$ soaked in $\mathrm{KMnO}_{4} 0,50 \%$ \\
\cline { 2 - 3 } & $\mathrm{K} 3$ & $\mathrm{~N} 3$ soaked in $\mathrm{KMnO}_{4} 0,75 \%$ \\
\cline { 2 - 3 } The Third Treatment $\left(\mathrm{H}_{2} \mathrm{O}_{2}\right)$ & $\mathrm{K} 4$ & $\mathrm{~N} 4$ soaked in $\mathrm{KMnO}_{4} 1,00 \%$ \\
\hline & $\mathrm{H} 1$ & $\mathrm{~K} 1$ soaked in $\mathrm{H}_{2} \mathrm{O}_{2} 5 \%$ \\
\cline { 2 - 3 } & $\mathrm{H} 2$ & $\mathrm{~K} 2$ soaked in $\mathrm{H}_{2} \mathrm{O}_{2} 10 \%$ \\
\cline { 2 - 3 } & $\mathrm{H} 3$ & $\mathrm{~K} 3$ soaked in $\mathrm{H}_{2} \mathrm{O}_{2} 15 \%$ \\
\cline { 2 - 3 } & $\mathrm{H} 4$ & $\mathrm{~K} 4$ soaked in $\mathrm{H}_{2} \mathrm{O}_{2} 20 \%$ \\
\hline
\end{tabular}

The three types of treatment are listed in Table 1. Untreated coconut fiber was given notation N. In the first treatment noted as $\mathrm{N} 1, \mathrm{~N} 2, \mathrm{~N} 3$, and $\mathrm{N} 4$, the fiber was soaked into $\mathrm{NaOH}$ solution with concentration as in table 1 each for 3 hours. After that the fiber was dried in an oven at a temperature of $90^{\circ} \mathrm{C}$ for 5 hours and then it was cooled to room temperature. In the second treatment noted as $\mathrm{K} 1, \mathrm{~K} 2, \mathrm{~K} 3$, and $\mathrm{K} 4$, the fiber that had been treated with $\mathrm{N} 1, \mathrm{~N} 2, \mathrm{~N} 3$, or $\mathrm{N} 4$ was soaked into $\mathrm{KMnO}_{4}$ solution with concentration as in table 1 each for 3 hours. After that the fiber was dried in an oven at a temperature of $90^{\circ} \mathrm{C}$ for 5 hours and then, it was cooled to room temperature. In the third treatment noted as $\mathrm{H} 1, \mathrm{H} 2, \mathrm{H} 3$, and $\mathrm{H} 4$, the fiber that had been trated with $\mathrm{K} 1, \mathrm{~K} 2, \mathrm{~K} 3$, or $\mathrm{K} 4$ was soaked into $\mathrm{H}_{2} \mathrm{O}_{2}$ solution with concentration as in table 1 each for 3 hours and then the fiber was dried in an oven at a temperature of $90^{\circ} \mathrm{C}$ for 5 hours. After that it was cooled to room temperature.

Tensile strength and strain of single coconut fiber was tested following ASTM 3379-02 by using a tensile testing LR10K Plus $10 \mathrm{kN}$ Universal Materials Testing Machine. The diameter of fiber ranging between $0.15 \mathrm{~mm}$ up to $0.55 \mathrm{~mm}$ was measured using a vernier caliper with $0.05 \mathrm{~mm}$ accuracy level. All measurement was done 4 times. The fiber surface morphology was examined using electron microscopy Vega3 Tescan Scanning Electron Microscope (SEM) at $5 \mathrm{kV}$ voltage and X-ray Diffraction (XRD) $30 \mathrm{kV}, 15$ $\mathrm{mA}$, at scan speed $2.000 \mathrm{deg} . / \mathrm{min}$. The crystallinity index $\left(\mathrm{I}_{\mathrm{C}}\right)$ of the fibers was calculated according to the Segal empirical method as follows [19]: 


$$
I_{C}=\left(\frac{I_{002}-I_{101}}{I_{002}}\right) x 100 \%
$$

where $I_{002}$ is the maximum intensity of the 002 lattice reflection and $I_{101}$ the intensity of diffraction. The crystallinyti index of coconut fiber of the first treatment is shown in Tabel 2.

\section{RESULTS}
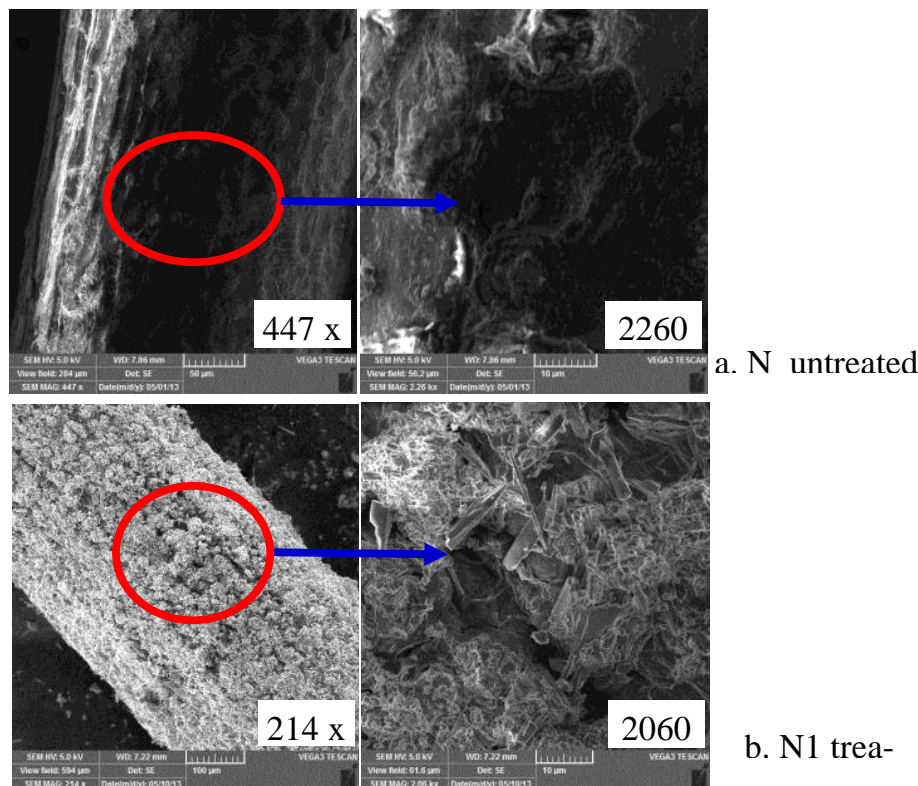

b. N1 trea-

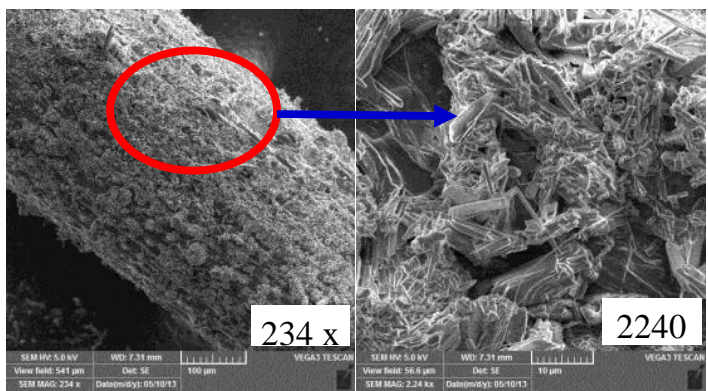

c. N2 trea-

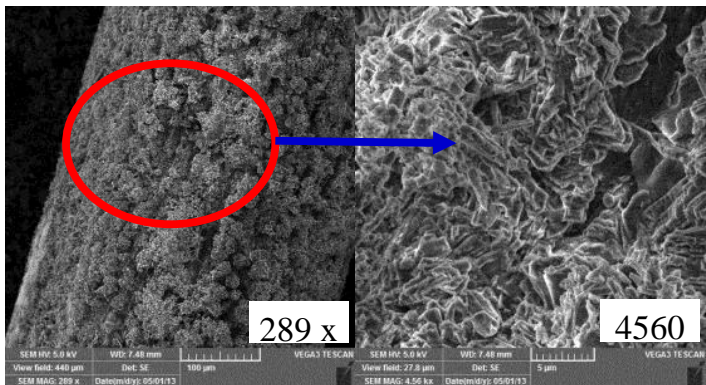

d. N3 trea-

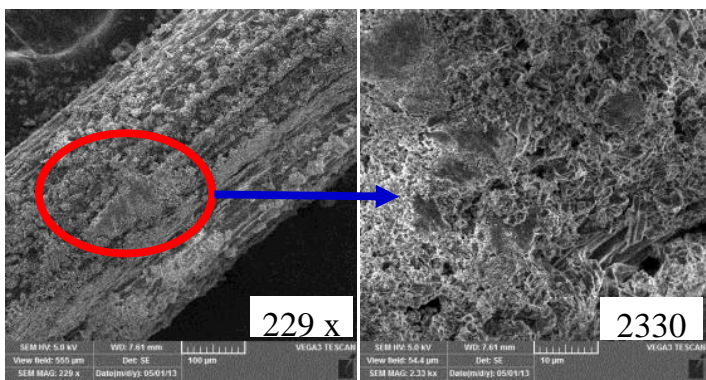

e. N4 trea-

Figure 1: Surface morphology of fiber without and with the first treatment 
Figure 1 shows SEM images of coconut fiber surface morphology. Figure 1a shows the surface morphology of the untreated fiber, Figure 1b-e shows that of coconut fiber that had been treated with $\mathrm{NaOH}$ (first treatment), Figure 2a-d shows the surface morphology of coconut fiber that has been given a second treatment $\left(\mathrm{NaOH}\right.$ then $\left.\mathrm{KMnO}_{4}\right)$, and Figure 3a-d shows that of coconut fiber that has been given a third treatment $\left(\mathrm{NaOH}\right.$ then $\mathrm{KMnO}_{4}$ then $\left.\mathrm{H}_{2} \mathrm{O}_{2}\right)$.
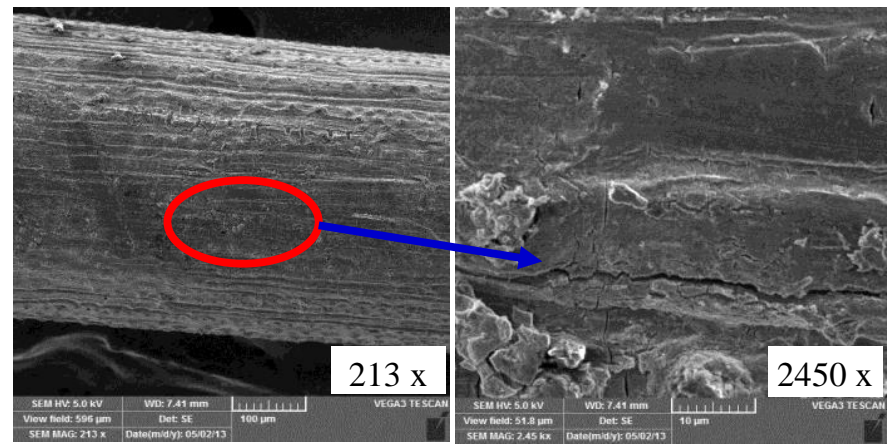

a. K1 treated
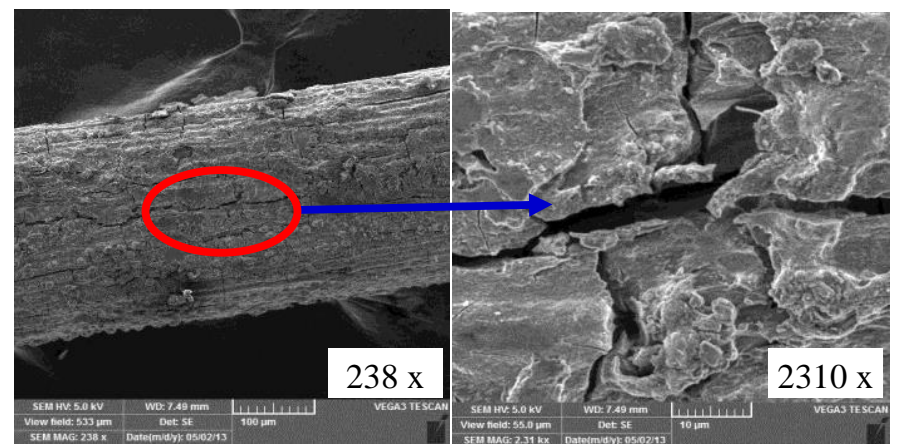

b. K2 treated
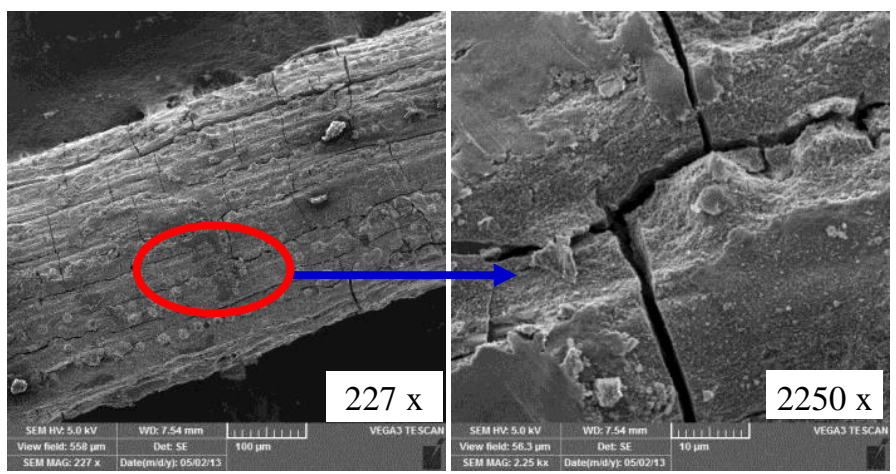

c. K3 treated
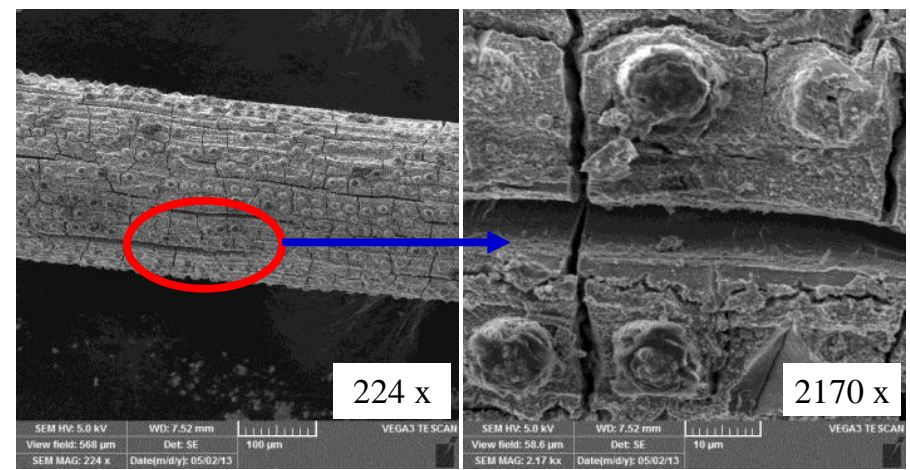

d. K4 treated

Figure 2: Surface morphology of coconut fiber with the second treatment

Figure 2a-d shows that the fibers treated with $\mathrm{NaOH}$ then $\mathrm{KMnO}_{4}$ causes grooves like trenches and an increase in roughness of the fiber surface. 

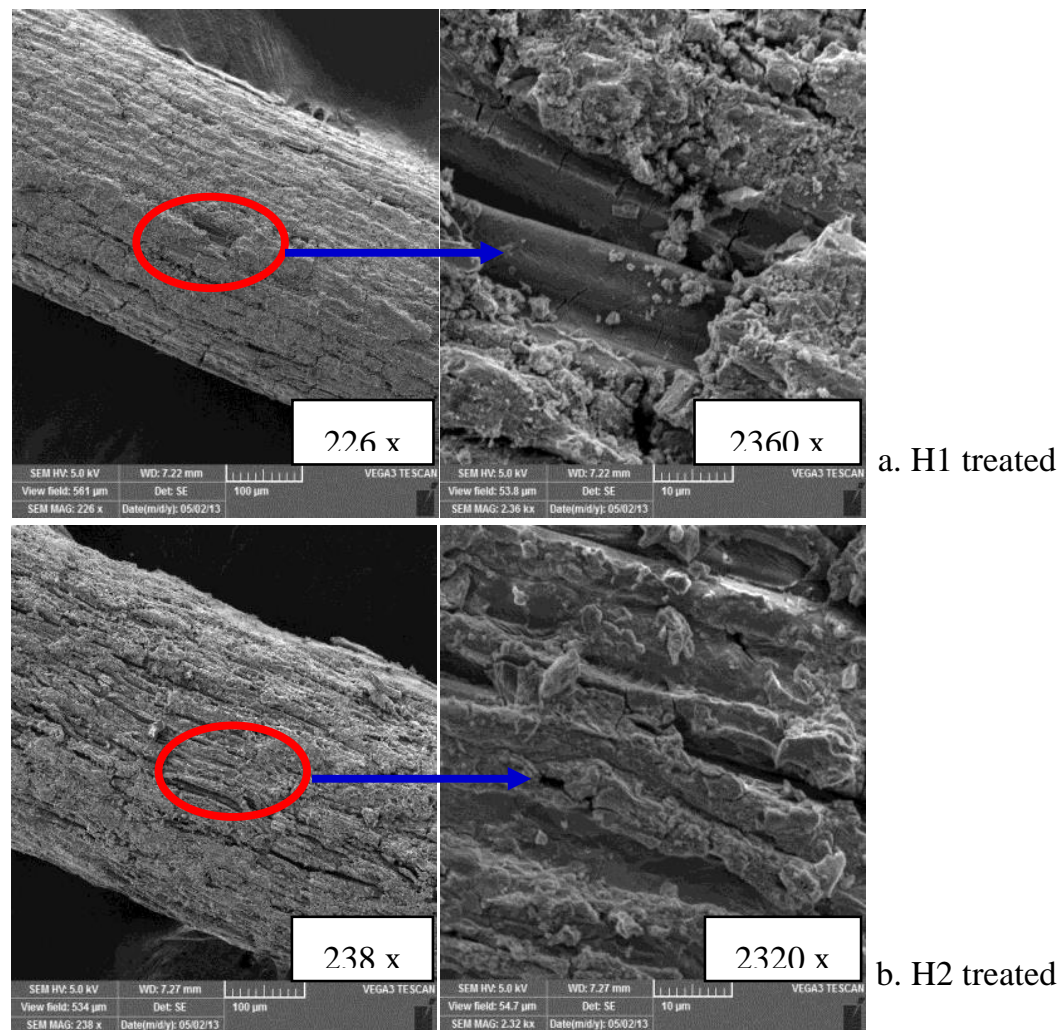

$\mathrm{H} 2$ treated

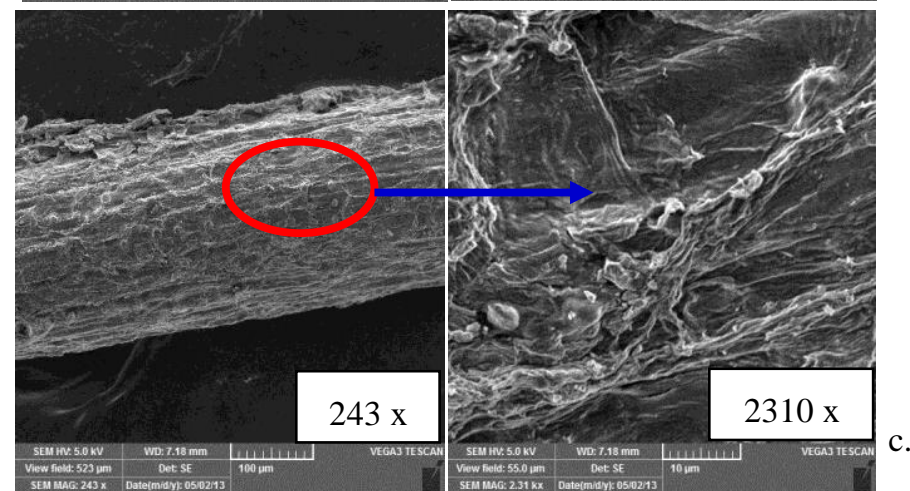

c. $\mathrm{H} 3$ treated
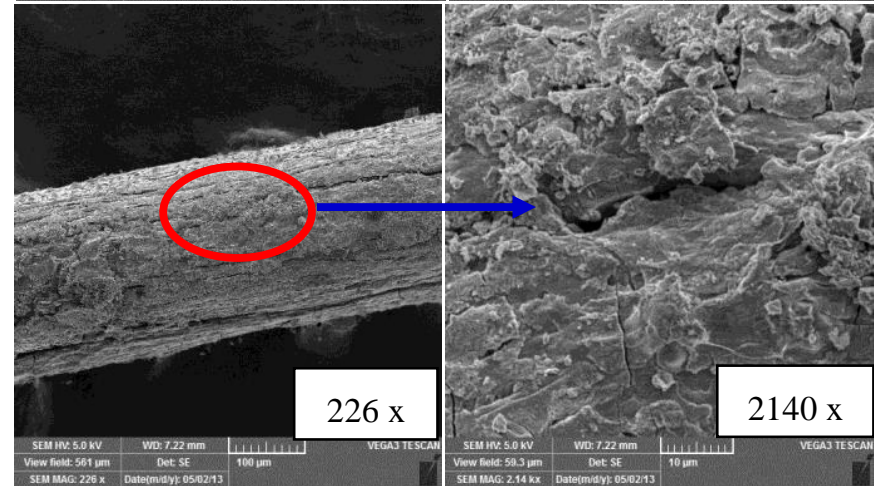

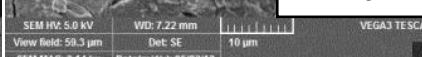

d. H4 treated

Figure 3: Surface morphology of coconut fiber with the third treatment 


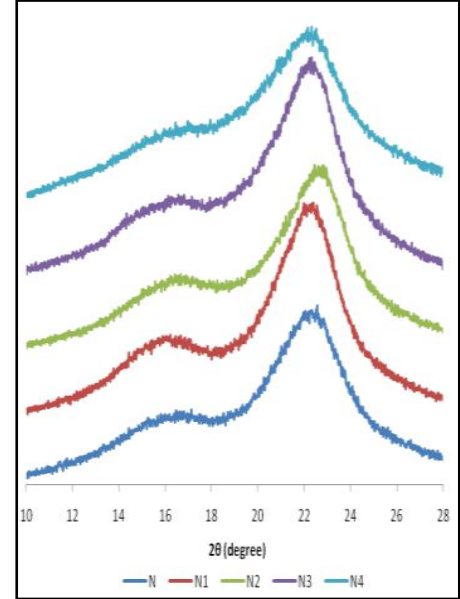

a. The First treatment

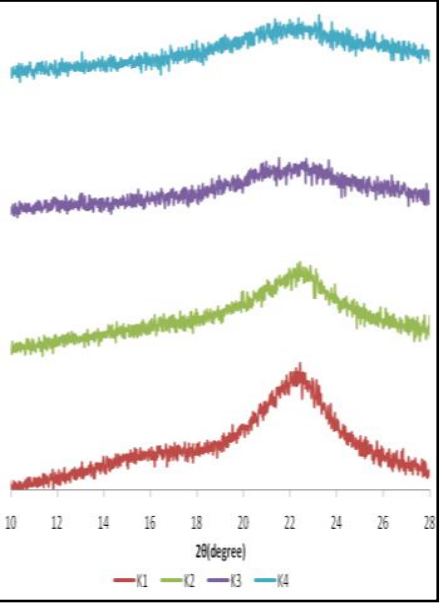

c. The second treatment

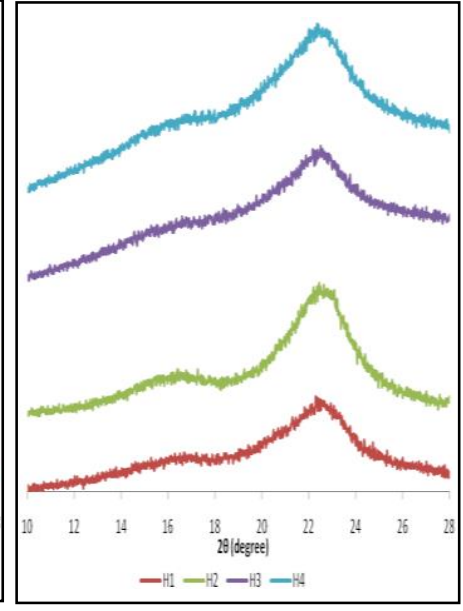

b. The third treatment

Figure 4: X-Ray Diffraction diagrams

Table 2: Criystallinity index for the first treatment

\begin{tabular}{c|c|c|c}
\hline TREATMENT & $\mathbf{I}_{(101)}$ & $\mathbf{I}_{(002)}$ & $\mathbf{I}_{\mathbf{c}}(\%)$ \\
\hline $\mathrm{N}$ & $2.116,11$ & $5.309,07$ & 60,14 \\
\hline $\mathrm{N} 1$ & $2.540,86$ & $6.745,58$ & 62,33 \\
\hline $\mathrm{N} 2$ & $2.101,42$ & $5.508,30$ & 61,85 \\
\hline $\mathrm{N} 3$ & $2.713,79$ & $7.019,27$ & 61,34 \\
\hline $\mathrm{N} 4$ & $3.179,72$ & $5.791,28$ & 45,09 \\
\hline
\end{tabular}

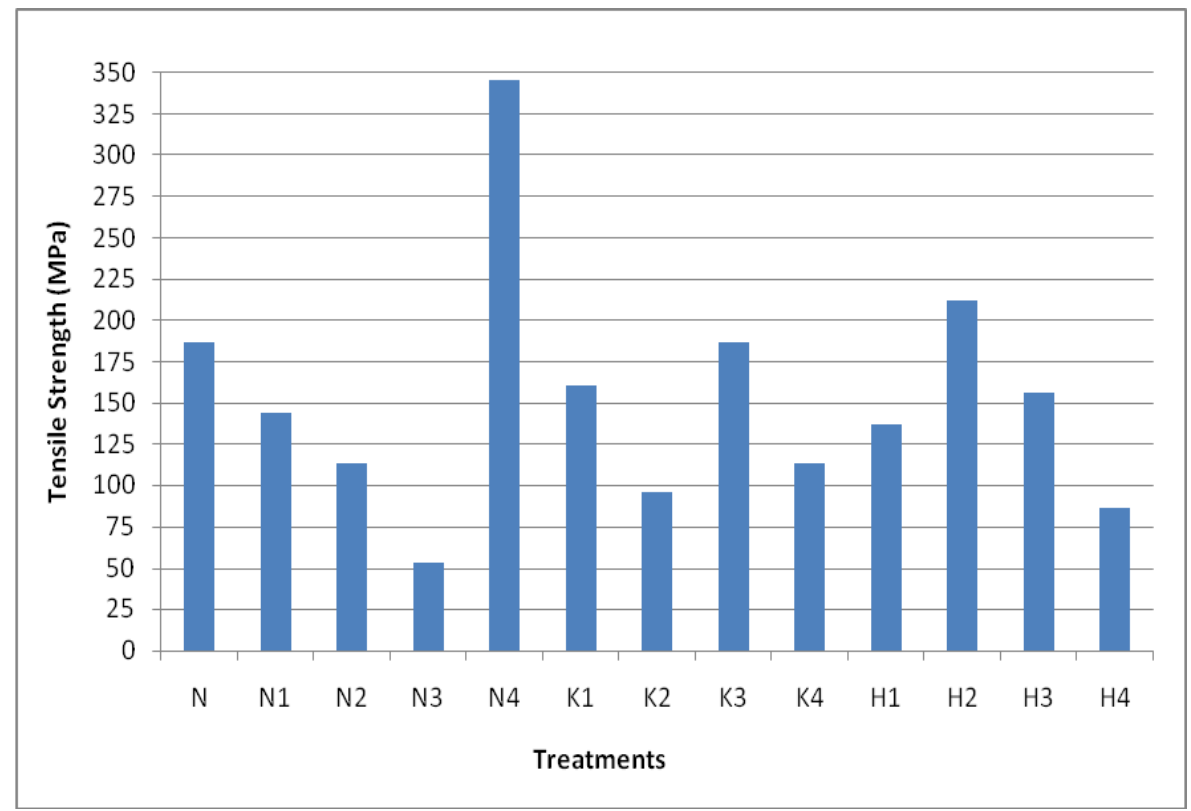

Figure 5: Tensile strength of coconut fiber at several treatments

Figure 4 shows the X-Ray Diffraction at three treatments. The figure shows that the X-Ray Diffraction is different at each treatment and Figure 5 shows the tensile strength of coconut fiber for all treatment. 


\section{DISCUSSION}

Figure 1a shows the untreated coconut fiber. The coconut fiber surface is rather smooth [10, 13]. This indicates that the fiber surface is still filled with impurities or other elements. Figure $1 \mathrm{~b}-\mathrm{e}$ shows the rough surface of the fiber due to the crystallization of $\mathrm{NaOH}$ solution for drying at a temperature of $90^{\circ} \mathrm{C}$ for 5 hours. Figure 1b-d shows large grain crystallizations whereas in Figure 1e shows small grains merge with each other so it looks sturdy. Alkali treatment makes the roughness of fiber surface very different from the untreated fiber surface $[8,10,13]$. Increased surface roughness of coconut fiber as the effect of increasing the amount of cellulose exposed []]. Nevertheless, the roughness is not permanent because crystallization of $\mathrm{NaOH}$ can be released easily when the fiber is soaked in other solution. This occurred after the fiber was soaked in a solution of $\mathrm{KMnO}_{4}$ as shown in Figure 2a-d. Fiber surface morphology showed that the crystallization $\mathrm{NaOH}$ disappears. Crystallization which is reduced or lost is also visible in Figure 4b, the XRD test results show an almost straight line except in the treatment of K1. Besides that, Figure 4 shows the diagrams of XRD for untreated and treated coconut fiber. Figure 4 a shows that the N4 line width peak of diffraction are the greatest. This means that the N4 treatment causes small crystallization with, crystallinity index of 45,09\% as show Tabel 2. It is clear that the decrease of the crystallinity on N4 treatment involving depolymerization, and it is evidence of the decrease of intensity [19].

Table 2 shows that the first treatment with $\mathrm{NaOH}$ decreases crystallinity index with increasing $\mathrm{NaOH}$ concentration. It is also reflected in the SEM results, decreasing of crystal size with increasing of $\mathrm{NaOH}$ concentrations. These results were also seen in the XRD profile in Figure 4a with the lower intensity peak, means that the smaller the crystals size [9]. Overall, if compare with fiber untreated, crystallinity index was increase after alkali treatment [20]. In the second treatment with $\mathrm{KMnO}_{4}$ solution change of the fiber surface morphology seen in the SEM results (Figure 2). These results is appropriate with the XRD results in Figure $4 \mathrm{~b}$ which shows a different of diffraction pattern with tendency of peak is lower for the second treatment. This indicates a loss of crystallinity due to the second treatment. In the third treatment with $\mathrm{H}_{2} \mathrm{O}_{2}$ solution, crystallization phenomenon was seen again with the appearance of the diffraction peaks as shows Figure 4c. However, based on morphological images obtained from SEM, there are differences of crystallized form that occurs between the first and third treatment. Crystallized form could be different between treatments due to the different chemical reactions that occur on the surface of the fiber. The phenomenon of crystallization in the third treatment may be caused by the reaction between cellulose with hydrogen [20].

The crystallization wrap up coconut fiber so that it becomes stronger. As a result, the tensile strength of the coconut fiber becomes larger than the other treated of fibers. The roughness looks tougher than that in Figure $1 \mathrm{~b}$-e. Grooves size is proportional to the concentration of $\mathrm{KMnO}_{4}$. Grooves are expected to facilitate the matrix to fill the grooves so that it can improve the bonding strength between the fiber and the matrix. Figure 3a-d shows that in the third treatment the grooves on the surface of the coconut fiber are covered by $\mathrm{H}_{2} \mathrm{O}_{2}$ solution in the form of patches. Although the fiber grooves covered by patches the tensile strength of the fiber tends to fall with increasing concentrations of hydrogen peroxide, as shown in Figure 5. This is due to the fact that the patches are not able to properly fill the grooves and does not become a single unit as seen clearly in Figure 3a-d. This results in the maximum strengths as shown in Figure 5, which is 345.78 MPa. This indicates that the coconut fiber soaked in $20 \% \mathrm{NaOH}$ solution have a significant effect on the surface of the coconut fiber. The maximum tensile strength increase of approximately $85.6 \%$ of the untreated fibers which is $186.33 \mathrm{MPa}$ [10]. This occurs because the fibers are covered by crystallized $\mathrm{NaOH}$ as shown in Figure 1e.

\section{CONCLUSIONS}

Three steps of chemical treatment have been applied on the coconut fiber. It can be concluded that:

1. Chemical treatment can change the surface morphology of coconut fiber to become rougher though its mechanical strength decreases slightly.

2. The first treatment leads to crystallization on the surface of the fiber, while the second treatment creates trench groove on the surface of coconut fiber.

3. Crystallization index is inversely proportional to the concentration of alkali solution.

\section{ACKNOWLEDGMENTS}

The author would like to thank all those who helped on the implementation of this experiment, especially to 
the head of State Polytechnic of Ujung Pandang, Makassar Academy of Industrial Engineering, State University of Makassar and the facilities that have been used.

\section{BIBLIOGRAPHY}

[1] WAIFIELATE, A.A., ABIOLA, B.O., Mechanical property evaluation of coconut fibre, Master's Degree Thesis, Department of Mechanical Engineering Blekinge Institute of Technology, Sweden, 2008.

[2] MUENSRI, P., KUNANOPPARAT, T., SIRIWATTANAYOTIN, S., at al. "Effect of lignin removal on the properties of coconut coir fiber/wheat gluten composite", Composites, v. 42, pp. 173-179, 2011.

[3] KHALIL, A.H.P.S., ALWANI, M.S., OMAR, A.K.M., et al., "Chemical composition, anatomy, lignin distribution, and cell wall structure of malaysian plant waste fibers", Bioresources, v. 1, n. 2, 220-232, 2006.

[4] ROZMAN, H.D., TAN, K.W., KUMAR, R.N., at al., "The effect of lignin as a compatibilizer on the physical properties of coconut fiber-polypropylene composites", European Polymer Journal., v. 36, pp. 1483-1494, 2000.

[5] DIXIT, S., VERMA, P., "The effect of surface modification on the water absorption behavior of coir fibers", Advances in Applied Science Research, v. 3, n. 3, pp. 1463-1465, 2000.

[6] SEN, T., REDDY, H.N.J., "Application of sisal, bamboo, coir and jute natural composites in structural upgradation”, International Journal of Innofation, Management and Technology, v. 2, n. 3, 186-191, June. June, 2011.

[7] ROSA, M.F., CHIOU, B., MEDEIROS, E.S., et al., "Effect of fiber treatment on tensile and thermal properties of starch/ethylene vinyl alcohol copolymers/coir biocomposites", Bioresource Technology, v. 100, pp. 5196-5202, 2009.

[8] AHAD, N.A., PARIMIN, N., MAHMED, N., et al. "Effect of chimical treatment on the surface of natural fiber", Journal of Nuclear and Related Technologies, v. 6, n. 1, pp. 155-158, 2009.

[9] CARVALHO, K.C.C., MULINARI, D.R., VOORWALD, H.J.C., et al., "Chemical modification effect on the mechanical properties of hips/coconut fiber composites", Bioresources, v. 5, n. 2, pp. 1143-1155, 2010.

[10] KARTHIKEYAN, A., BALAMURUGAN K., "Effect of alkali treatment and fiber length on impact behavior of coir fiber reinforced epoxy composites", Journal of Scientific \& Industrial Research, v. 71, pp. 627-631, September, 2012.

[11] KARTHIKEYAN, A., BALAMURUGAN, K., KALPANA, A., et al., "The new approach to improve the impact property fiber reinforced epoxy composites using sodium laulryl sulfate treatment", Journal of Scientific \& Industrial Research, v. 72, pp. 132-136, February, 2013.

[12] AZMI, M.A., YUSOFF, M.F.C., ABDULLAH, Z.A., et al., "Rigid polyurethane foam reinforced coconut fiber propoerties", International Journal of Integrated Engineering, v. 4, n. 1, pp. 11-15, 2012.

[13] MULINARI, D.R., BAPTISTA, C.A.R.P., SOUZA, J.V.C., et al., "Mechanical properties of coconut fibers reinforced polyester composites", Procedia Engineering, v. 10, pp. 2074-2079, 2011.

[14] LAI, C.Y., SAPUAN, S.M., AHMAD, M., et al. "Mechanical and electrical properties of coconut coir fiber-reinforced polypropylene composites", Polymer-Plastics Technology and Engineering, v. 44, pp. 619632,2005

[15] HUSSAIN, S.A., PANDURANGADU, V., PALANIKUAMR, K., et al., "Mechanical properties of green coconut fiber reinforced HDPE polymer composite", International Journal of Engineering Science and Technology, v. 3, n. 11, pp. 7942-7952, November, 2011.

[16] FERRAZ, J.M., MENEZZI, C.H.S.D., Teixeira, D.E., et al., "Effect of treatment of coir fiber and cement/fiber ratio on properties of cement-bonded composites", Bioresources, v. 6, n. 3, pp.3481-3492, 2011.

[17] YAO, J., HU, Y., LU W., et al., "A wood replacement material of sandwich structure using coir fiber mat and fiberglass fabrics as core layer", Bioresources, v. 7, n. 1, pp. 663-674, 2012.

[18] ABDULLAH, NURUL MUNIRAH., and AHMAD, ISHAK., "Effect of chemical treatment on mechanical and water-sorption properties coconut fiber-unsaturated polyester from recycled PET", International Scholarly Research Network (ISRN) Materials Scince, 2012.

[19] MAHATO, D, N., PRASAD, R, N., MATHUR, B, K., "Surface morphological, band and lattice structural studies of cellulosic fiber coir under mercerization by ESCA, IR and XRD techniques", Indian Journal of Pure \& Applied Physics, v. 47, pp. 643-647, 2009. 
[20] SINHA, E., ROUT, S, K. "Influence of fibre surface treatment on structural, thermal and mechanical properties of jute fibre and its composite”, Bull Material Science, v. 32, n.1, pp. 65-76, 2009. 